\title{
Spatial Planning for Future Risk Reduction in Coastal Area (Case Study: Kalanganyar Village, Sidoarjo)
}

\author{
Fairuz Mutia $^{{ }^{*}}$, Adibah Nurul Yunisya ${ }^{1}$, and Eva Elviana ${ }^{l}$ \\ ${ }^{1}$ Department of Architecture, Universitas Pembangunan Nasional "Veteran" Jawa Timur, Jl. Raya \\ Rungkut Madya, Surabaya, 60294, Indonesia
}

\begin{abstract}
There is an urgent need for cities to consider disaster and climate change issues. Disasters have caused major disruptions in low- and middleincome countries, often wiping out decades of development benefits in a few moments. Including Kalanganyar, which is geographically located in the hazard-prone. This village has no sandy beach area and directly facing the mangrove forest as the outermost boundary. Since $2 / 3$ of the area is aquaculture, this has resulted in some areas lacking adequate mangrove forests. Therefore, Kalanganyar area becomes prone to tsunami hazards as well as river/tidal flooding. Therefore, disaster risk assessment is needed as input data in spatial planning and spatial planning of Kalanganyar Village as a disaster preventive action. This research is qualitative research with a phenomenology approach. The results of the data tape were analyzed by synchronic reading. Character appraisal is used to assess the eight principles of urban resilience design. The goal is to produce an anticipatory spatial planning concept for the natural disaster, the existing disaster of natural disasters but also human-caused disasters. From the results of character appraisal reading on the area, it was found that the urban fabric is less resilient. This is also coupled with some of the more frequent natural disasters that are floods and tsunamis. This then becomes the basis for the spatial development of disaster-prone areas and meets the overall parameters. Spatial area arrangement is done to anticipate future and future disasters, with more compact urban fabric arrangement, restoring ecological mangrove function according to standard, and also equitable distribution of village facilities and infrastructure so that the area is well developed and planned. This research can be a good and appropriate preventive action for the region.
\end{abstract}

\section{Introduction}

\subsection{Problems Background}

\footnotetext{
* Corresponding author : fairuzmutia.ar@upnjatim.ac.id
} 
The rapid urban expansion of this globalization era is largely unplanned and makes more people and economic assets vulnerable to disaster risk and climate change. There is an urgent need for cities to consider disaster and climate change issues [1]. Disasters have caused major disruptions in many countries, often wiping out decades of development benefits in a few moments. The last major disaster in the development of countries including the earthquake in Haiti (early 2010) that killed more than 220,000 people and in Indonesia (2009) that killed more than 1,000, Nargis cyclone in Myanmar (2008) which killed more than 138,000 people, and the Sichuan earthquake in China (2008) that killed more than 87,000 people [1]. With various types of hazards that can happen just like that, the assessment of disaster risk is in fact minimally done in a place that has not been affected by any disaster. This leads to less anticipatory risks thereby enlarging the effects of disasters that will occur.

Kalanganyar village itself is a coastal area that $2 / 3$ of its area is a huge aquaculture pond. On the east side of the village is a coastal area planted with mangrove forest which does not have a transition area of sandy beach. Since the majority of the land is aquaculture, this has resulted in some areas lacking adequate mangrove forests and also infrastructure. Moreover, the river border conditions have no good green area arrangement. This bareness makes river water overflows and swamping the aquaculture area and causes crop failure. This is exacerbated by the waste of fish discharged directly into the river in the absence of adequate waste treatment.

Natural conditions that are now turned into a built environment then accommodate their human needs, Kalanganyar is a different area. With the existence of different settlement conditions, resulting in several natural disasters that did not initially occur now, such as floods and sea water abrasion. Some small tsunamis also occur, even though they have not yet entered the residential areas but are quite harmful because they have failed to harvest from the ponds. With climate conditions becoming more extreme lately, without being balanced with good spatial planning, ecology that was initially very environmentally friendly has become a hazard prone area that needs to be reexamined Therefore, disaster risk assessment is needed in the coastal area in this area as well as input data in the spatial planning of Kalanganyar Village as a disaster preventive action.

\section{Methods}

This research is qualitative research using quantitative and qualitative data. The approach is using phenomenology [2]. Phenomenology according to Norberg-Schulz [3] can be seen as a tool to see the symptoms that can be absorbed by the senses as a phenomenon. Using three pillars of urban risk assessment (institutional, hazard impact, socioeconomic) criteria according to World Bank [1], researchers analyzed data that had been captured and interpreted synchronically [4].

This assessment is done only on the primary levels because the main focus of research is on the spatial arrangement of the region as a disaster preventive action. In this case the process of analyzing the researcher to 'synchronize' or synchronize various information obtained at the same time. Then character appraisal analysis techniques [5] were conducted to analyze the eight principles of urban planning resilience [6]. The results of this analysis are then synchronized again with the result of the urban risk assessment that has been done. The synthesis of data is then used as a reference in the spatial arrangement of the region.

\section{Results and Discussion}

Kalanganyar village is largely an aquaculture area. There are groupings in residential areas and areas specifically developed as aquaculture areas. In general mapping, it can be seen that 
the land use of the village as follows (Figure 1). In this mapping, it can be seen that the existing condition of the majority village is a pond area. On the eastern side bordering the sea there are several mangrove forests. Some access roads to this area cannot be passed by four-wheeled vehicles. If the rivers were overflow, then the two-wheeled vehicles also need special specifications to get through this muddy road. By using this mapping, it is reviewed first in accordance with the existing urban risk assessment pillars

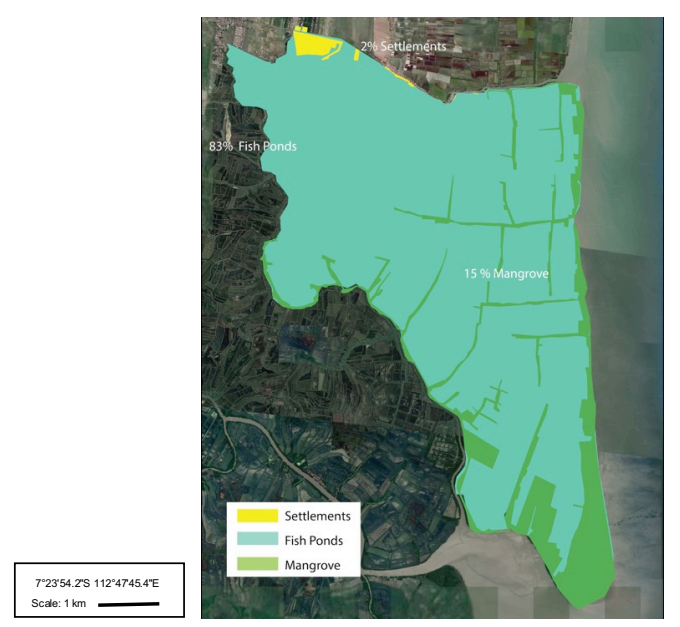

Fig. 1. Kalanganyar Village Land Use

According to the United Nations International Strategy for Disaster Reduction (UNISDR), the 5-hazard category are geological hazards, hydrometeorological hazards, biological hazards, technological hazards, and environmental hazard. Complementing the 5hazard category, high vulnerability of communities, infrastructure, and city elements urging a disaster preventive measure, starting from the beginning of the disaster mitigation phase. Disaster mitigation is a series of efforts to reduce disaster risk, both through physical development and awareness, and enhancement of the ability to face disaster threats [4]. This disaster mitigation phase is a cycle of disaster preparedness up to the response during a disaster [7]. In response to that, BNPB Strategic Policy 2015 - 2019 oriented to increase the number of disaster mitigation studies. Most disaster mitigation activities are focused on environmental, physical, and geological assessments. Whereas spatial planning or spatial planning bridges the gap between adaptation and mitigation [3]. With good space planning, not only disaster mitigation and disaster risk reduction, the city will be able to grow sustainable and resiliently, therefore urban risk assessment needs to be conducted.

\subsection{Hazard Impact Assessment}

\subsubsection{Sea Rise/Tidal Flooding Hazard Impact}

The hazard impact assessment focuses on understanding hazard trends, and identifying populations and physical assets at risk of future hazards and impacts from increased climate variability [6]. The results of the depth interview showed for the last 3 years, the owners of the aquaculture pond can be said failed to harvest. In these 3 years, the river flooded the pond area and made the fish seeds out of the pond and freely swam to the river. This flood is likely the effect of the tide that once every year changes time $(6$ months tide during the day, 6 months tide at night). 


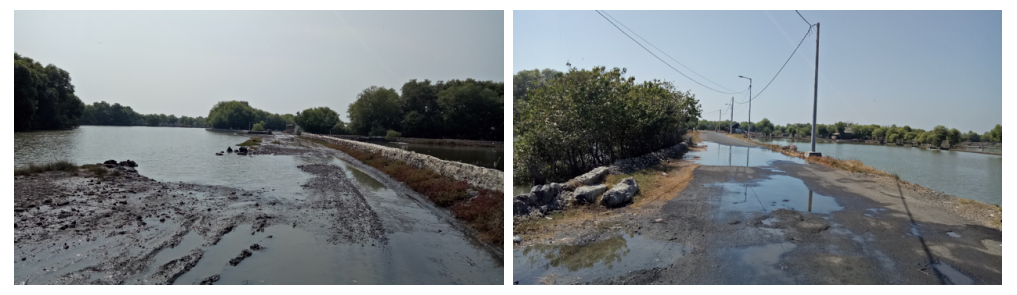

Fig. 2. River/Tidal Flooding impact in Kalanganyar Village

This river/tidal flooding surely affects the economy aspect of citizens, also damage the assets of residents in the form of houses, crops, aquaculture and livestock. The floods also damaged the infrastructure of the area in the form of roads and access that cannot be traversed by the mud.

\subsubsection{Tsunami Hazard Impact}

In the year 2003 there was a small earthquake and tsunami tremor that occurred in the village. Some of the closest fishponds from the coastline are vibrating indicating a tsunami hazard potential. According to data from BPS Sidoarjo [8], Kalanganyar Village area has a height of only 4 meters from sea level which makes this area prone to disaster.

\subsection{Institutional Assessment}

The institutional assessment aims to aid in developing an effective institutional policy for managing disaster and climate change risk. In this case, the most involved in the local government. Currently, there has been no education or other preventive action on disaster mitigation. There is a need for hazard impact assessment which then produces the hazard mapping prone as a base to review further action of future disaster risk. Local and provincial governments should conduct more detailed mapping of disaster-prone locations. This mapping is followed up by technical and non-technical preparations so that it will be ready for disaster and post-disaster.

\subsection{Social - Economic}

The citizens in the east area were affected financially due to the occurred disaster (Figure 3). One of the pond owners claimed that within the past 3 years they are unable to harvest their fishes because of the floods which flow through their ponds and carry their fishes away. Sidoarjo. With an area of 4.101.57 Ha of seawater which is the largest saltwater area in Sidoarjo, it also causes difficulty of clean water supply especially on the east side of the area. To overcome the freshwater crisis, the pond owner has to buy tanked clean water to fulfill their daily needs. This condition is significantly different compared to the cluster of settlements on the west of Kalanganyar where accessibility, electricity and also clean water from the water ground are easily accessible. From the synchronic analysis above, it is found that Kalanganyar Village possesses a natural disaster threat which consists of river flood and tsunami. Furthermore, the urban development which separates the residents' settlements from the aquaculture area leads to a gap of infrastructure and facility development between the west and the east area of Kalanganyar Village. Therefore, the social-economic of Kalanganyar east area severely affected by the disaster and the recovery are unable to be efficiently executed due to the lack of supporting infrastructure. 


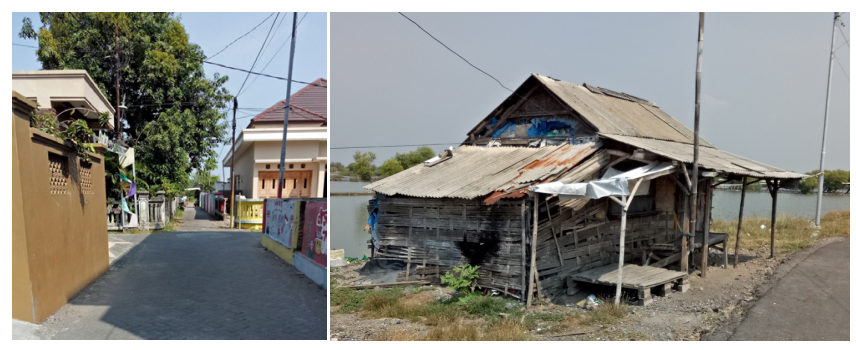

Fig. 3. Differences between west area of Kalanganyar and east area of the village

\subsection{Kalanganyar Village as resilience urban area}

For cities, resilience stands for the ability to adapt to a rapidly changing environment. Kalanganyar village itself, in addition to being a hazard-prone area also has an urban fabric that is quite unique, specifically the separation between residential areas and aquaculture as working areas. In his research, Salat \& Bourdic (2014) put forward 8 basic principles of urban resilience. These eight principles are reviewed to determine the physical condition of the vulnerability of the village of Kalanganyar and how the solution is.

\subsubsection{Compact Densification}

In accordance with the existing data area, there are differences in the density of both the building and the occupant population in the two major poles of the area. The west area, which is closer to the primary artery road has a high density (Figure 4). The existence of government buildings in the form of Village Head Office and also facilities - education and health facilities make this area densely populated. In the eastern area, the majority of the density aquaculture area is quite low, because it is only dominated by aquaculture and some houses residents who are on the edge of the river.
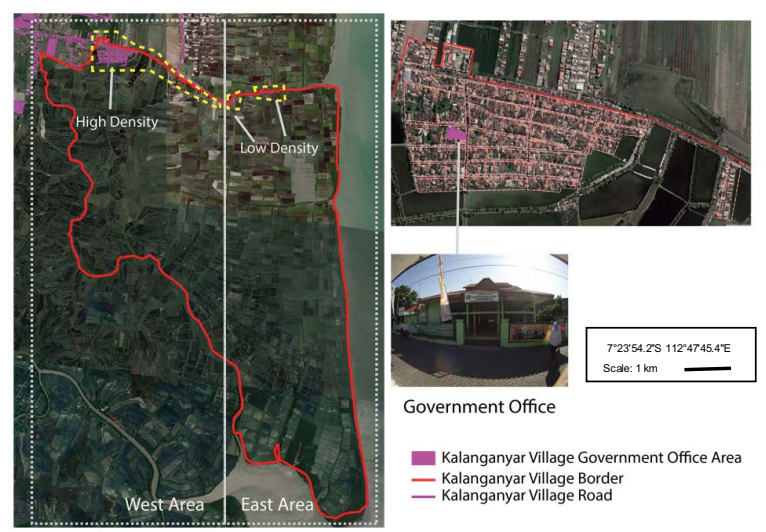

Government Office

Kalanganyar Village Government Office Area — Kalanganyar Village Border — Kalanganyar Village Road

Fig. 4. Density Comparison Kalanganyar Village 


\subsubsection{Scaling}

Scaling is an aspect in the arrangement of the city's resilience. Salat and Bourdic [6] show the same dimension of the road in Paris, both in the city and on the neighborhood and district scale. Local and global are connected by a series of consecutive connections that show structure and organization at every scale. This is called a scaleless structure. In Kalanganyar Village itself, in accordance with existing mapping, there are few different scales in the area located on the east of the area. If on the west side there is a dimension of the road scale that has different width according to its function, then in the eastern area most of the pond does not have the same dimensional transition as the western area.

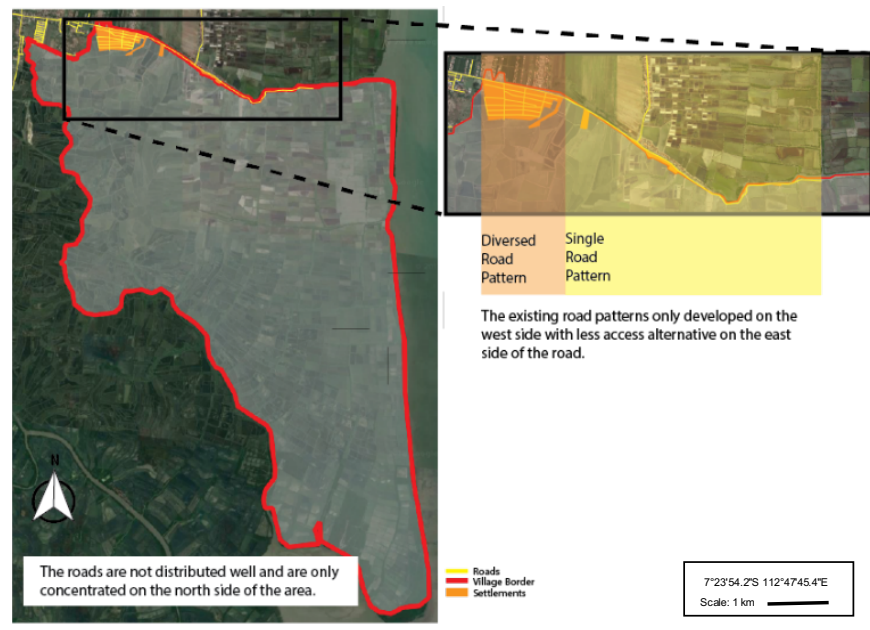

Fig. 5. Road distribution in Kalanganyar village

This resulted in the least population in the eastern area, because it only has one access road only. If there is tidal flooding, then this road area cannot be used. Road development is also an obstacle because muddy road access is still the only way. The use of less diverse land use also prevents every part of the village into a self-sufficient area. In the scale of the area, of course, the arrangement of land use is sufficient because in one village there is already an area of education and other public facility areas. However, when viewed in more detail, the division of commercial areas and settlements more developed on the west side of the area. The eastern area is destined to be the home of fish ponds and grass, but less developed because it is not supported by other more primary functions. It is necessary to add a primary function as a growth stimulus on the east side and use the same road scale so that there is no growth imbalance.

\subsubsection{Functional Flexibility, Fine Grain Diversity, and Synergy}

There are several potentials for flexible changes to be found in major roadside areas of Kalanganyar Village. Some homes are now used as residential-businesses. However, the majority of these areas are included in mono functional housing development. This indicates that the lack of functional flexibility which is apparent in the urban pattern of Kalanganyar due to the separation of the work area with the residential area. This resulted in the absence of good diversity in the area, so people have to travel far enough to get to the work area. Therefore, the area becoming less resilient as more people use private vehicles and produce carbon footprint. Furthermore, the density in the western area of Kalanganyar Village in considered to be quite diverse compares to the east side. The density diversity resulted in a fairly good growth in the region, while the eastern side tends to be less developed and does 
not show good synergy with the area due to the lack of density. This is because the area is used mainly as a fish pond which means that it is a passive area with minimum active activity by the citizen. Therefore, it is necessary to restructure the land use in the area of Kalanganyar Village to be able to accommodate jobs that can be close to the houses of its citizens.

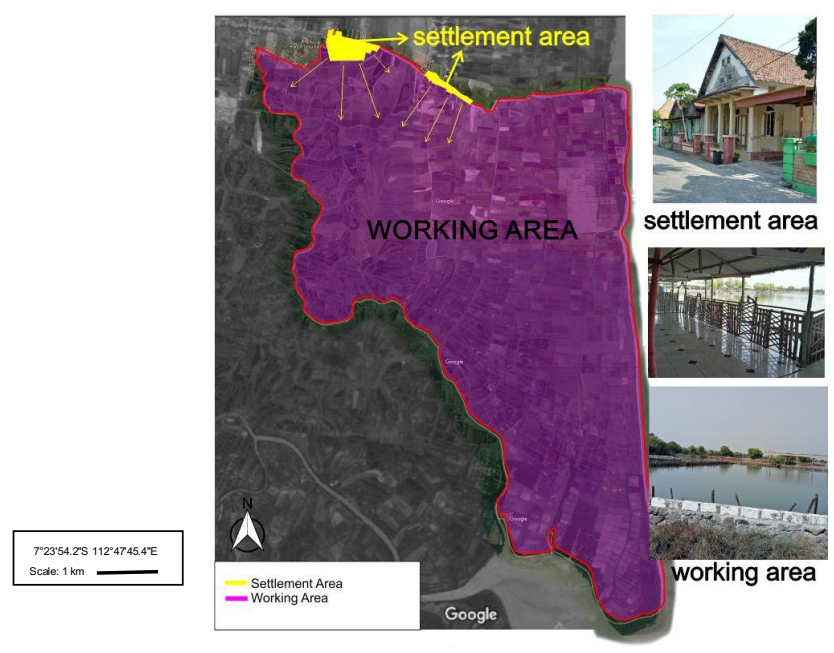

Fig. 6. Mapping of fine grain diversity in Kalanganyar village

\subsubsection{Urban-Rural Integration and Highly Connected Networks}

Urban-rural integration explains the connectivity of Kalanganyar Village with the urban spatial structure. As a rural area, access roads to urban areas are only possible through one access road. This indicates that basically, Kalanganyar Village is already connected do the city center, although only through one access road only.

In an emergency situation, citizens need to be able to evacuate themselves immediately. A highly connected network would help the people to evacuate faster as they evacuate themselves to safer ground. However, in an emergency situation, people tend to be in such distress that they are having problems in proceeding to the evacuation route [9]. Network connection for evacuation route expected to possess good way finding which embrace the natural movement so that people manage to evacuate themselves in distress situation. In the creation of good and balanced street connectivity, it requires varied street typology with adjacent land use and street character. Furthermore, according to Dickson et al [1], balanced network should include human-friendly accessibility which considers highly walkable, human scale, dense, fine grain, a densely connected network that prioritizes on accessibility improvement and walking access recognition. Moreover, balancing the street network required wider streets that connect part of cities which complemented the public transportation system.

In Kalanganyar Village, the official street networks are only present about 5\% of the area. Leaving the rest as passive mobility area which is not used for public or even daily activity. The available network infrastructure is proper enough to be used by the citizen to mobilize by car, motorcycle, and bicycle and by foot (Figure 7). Interestingly, the nearest river was also used as part of network mobility. The citizen who resides right next to the river manages to 'park' their boat in front of their houses (Figure 7). This habit puts river as part of their network connections to mobilize from their house to other parts of the city. 

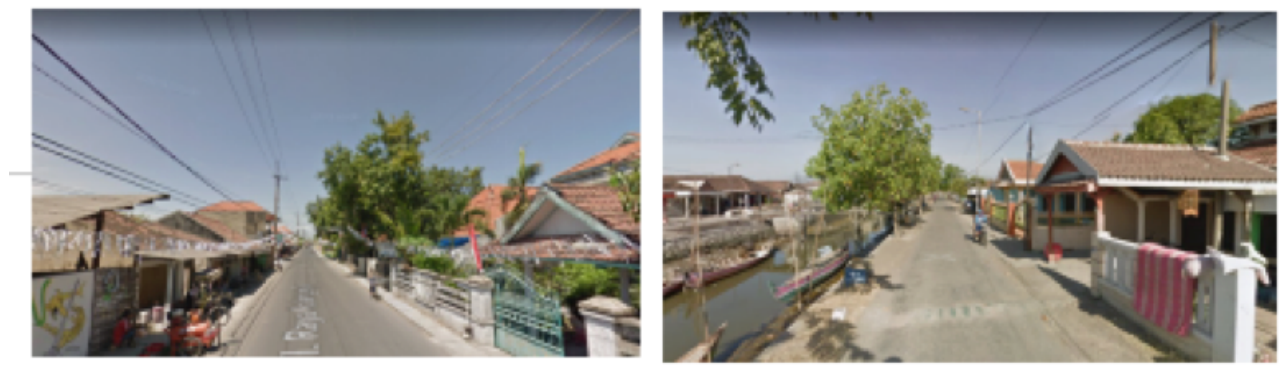

Source: Google Street View, accessed at $26^{\text {th }}$ October 2019

Fig. 7. Existing street network condition (left) and boat parking dock in front of the inhabitants residential in Kalanganyar (right)

According to the existing road network street network in Kalanganyar Village does not indicate good balance of the street network. Firstly, the road networks are not distributed well throughout the village. The evenly built networks are only concentrated on the west side of the Village, while on the east side the there is only one street networks which underlay almost to the border of the village. Secondly, the street network only concentrated on the north of the area and only provide limited connections to another village. In figure 8 , it can be seen that the available street network in Kalanganyar Village only connected by intersections to other villages. Nevertheless, the developed street connection sufficiently facilitates the present settlement that is existed in Kalanganyar Village.

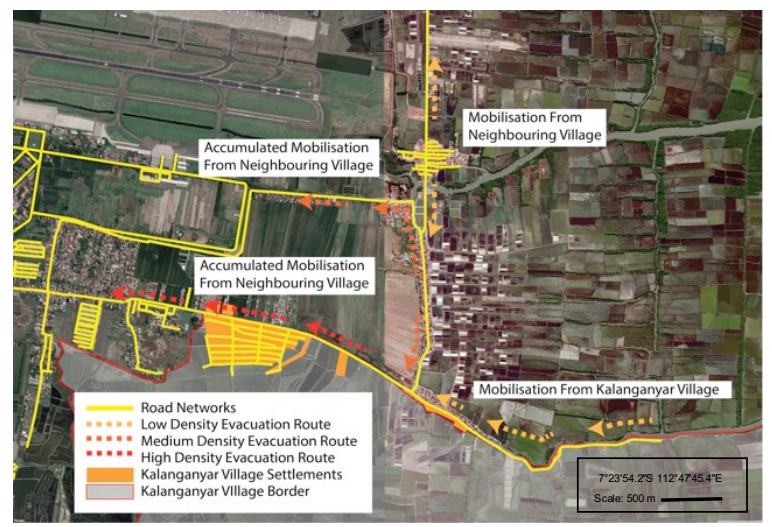

Fig. 8. Evacuation Route in Kalanganyar Village

In response to the disaster resilience, the street configuration in Kalanganyar Village is considered to be very limited for emergency evacuation mobility. With only two potential exit routes, the existing street network in Kalanganyar Village is not sufficient for the citizen evacuation route (Figure 8). With the existed evacuation route, the main road located in Kalanganyar Village is also becoming the main evacuation route by the neighboring village. Within the radius of 800 meters, the potential evacuation route is accumulated in Kalanganyar main road. Meanwhile for the area outside the $800 \mathrm{~m}$ radius was provided by an alternate evacuation route, therefore it will not be accumulated in Kalanganyar main road. With the high-density evacuation route, this route becoming unideal for an emergency situation as it might over-dense with evacuation mobilization. Therefore, the evacuation route in Kalanganyar Village and the surrounding area needs to be adjusted with the mobilization needs, especially in an emergency situation. 


\subsubsection{Greening and Water Recycling}

The condition of Kalanganyar Village which consists of $2 / 3$ of fishponds area is a condition that is quite apprehensive. Some areas of the pond certainly sacrifice the most important areas for coastal areas, namely mangrove forests. Mangrove forests can reduce wave heights by half a meter. If viewed according to mapping analysis of existing mangrove vegetation, most of the mangrove forest is located in the east of the area.

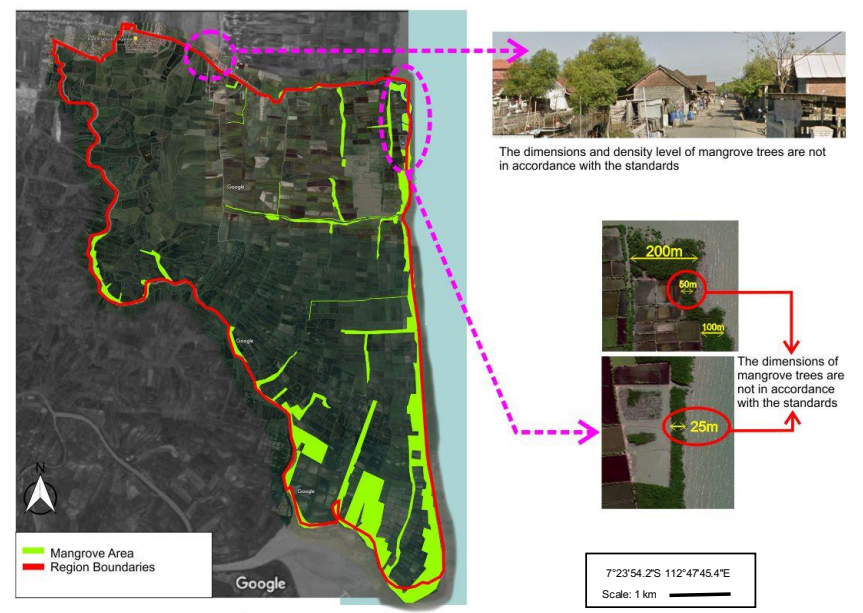

Fig. 9. Mapping of mangrove area in Kalanganyar village

From the results of the existing mapping, it can be seen that the mangrove density at the riverbank area is only about $10 \%$ which is located in the easternmost area and $0 \%$ on the western side of the settlement. In fact, according to the Decree of the Minister of Environment the main requirement of mangrove forest plots to prevent river abrasion and flooding is 50 meters to the left and to the right of the highest tidal line of river water which is still influenced by the tide of seawater. So currently, there has been a flood caused by tidal seawater with no mangrove that can break the waves. Eventually, the tide might flood into the inhabitant's settlements and causes the failure of pond harvest.
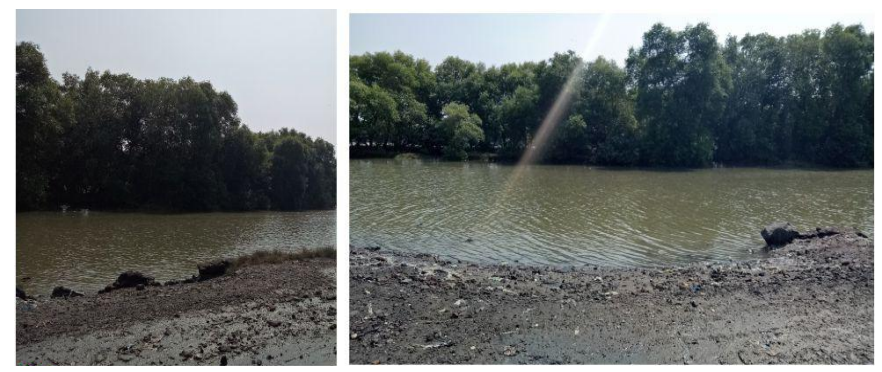

Fig. 10. Mangrove conditions in the riverfront area

Correspondingly, on the beach conditions where there is a stretch of silt (mudflat), a 100meter boundary from the highest tide line is used. If viewed from the results of the mapping that has been carried out, several points of the existing mangrove forests still do not meet the standards. This has caused the coastal area to be prone to storms and typhoons, as well as abrasion and absorbing waves of seawater. 


\section{Conclusions}

Kalanganyar village located in the coastal area cannot escape from the potential of natural hazards, such as river / tidal flooding and tsunami. Some conditions of natural barriers on the river and shoreline do not meet the standards. With such condition, an adjustment needs to be done to meet the required standard. This needs to be done so that disasters that may arise can be minimized. Spatial structuring of the riverbanks must conform to government regulations, which is $50 \mathrm{~m}$ from the river shore. A review of the ten principles of village resilience was also undertaken as an anticipatory measure of human hazard. The effect of lack of local anticipation causes too much discharge of gas emissions as well as social inequities that can result in human-caused disasters. Furthermore, the uneven development that is concentrated only on the west side of the region resulted in facilities and infrastructure that did not develop on the eastern side of the region. In this regard, it is necessary to develop both road infrastructure and facilities. Variations in the use of land use and development of facilities need to be developed in the eastern area of the region. Adjustment of the border for mangrove planting also needs to De implemented in order to prevent abrasion as well as tidal flooding, considering the height condition of Kalanganyar Village only $2.5 \mathrm{~m}$ above sea level.

With good spatial planning, the potential hazard of handlers in Kalanganyar Village can be minimized. Tsunami or flood self-rescue routes can be implemented through existing spatial planning, by adding new routes. It is necessary to re-examine the level of speed and self-rescue models of new spatial planning, to achieve the objective of structuring the environment which is also free from danger.

\section{References}

1. E. Dickson, J. L. Baker, D. Hoornweg, and T. Asmita, Urban risk assessments: an approach for understanding disaster and climate risk in cities. The World Bank, 2012.

2. L. N. Groat and D. Wang, Architectural research methods. John Wiley \& Sons, 2013.

3. C. N. Schulz, The Concept Ot Dwelling: On the Way to Figurative Architecture. Rizzoli International Publications, 1985.

4. E. T. S. Darjosanjoto, "Penelitian Arsitektur di Bidang Perumahan dan Permukiman." Surabaya: ITS press, 2006.

5. M. for the Environment, Urban Design Toolkit Third Edition. New Zealand, 2006.

6. S. Salat and L. Bourdic, "Spatial Planning Principles \& Assessment Framework For Climate Adaptive \& Resilient Cities in China," 2014.

7. BPBD Kabupaten Karanganyar, "BPBD Kabupaten Karanganyar."

8. B. Sidoarjo, "Sidoarjo dalam Angka," 2017.

9. N. I. Mohareb, "Emergency evacuation model: accessibility as a starting point," Proc. Inst. Civ. Eng. - Urban Des. Plan., vol. 164, no. 4, pp. 215-224, Dec. 2011. 